\title{
Glosa do uchwały Sądu Najwyższego z dnia 17 lutego 2016 r., sygn. III CZP 111/15
}

\section{Wprowadzenie}

Przewidziany w prawie zamówień publicznych system środków ochrony prawnej, ze względów ustrojowych ${ }^{1}$, a także proceduralnych ${ }^{2}$, jest źródłem licznych problemów zarówno natury teoretycznej, jak i praktycznej. Nad jednym z nich pochylił się Sąd Najwyższy (SN) w uchwale z 17 lutego 2016 r. ${ }^{3}$ wydanej na skutek przedstawienia mu zagadnienia prawnego. Sąd okręgowy, rozpoznając skargę na orzeczenie wydane

${ }^{1}$ J. Niczyporuk, Krajowa Izba Odwoławcza - organ administracji regulacyjnej, w: Nowe podejście do zamówień publicznych - zamówienia publiczne jako instrument zwiększania innowacyjności gospodarki i zrównoważonego rozwoju. Doświadczenia polskie i zagraniczne, Materiały pokonferencyjne IV Konferencji naukowej UZP, Kazimierz Dolny 2011, s. 105-110; K. Solecka, Pozycja prawnoustrojowa Krajowej Izby Odwoławczej, w: Kontrola zamówień publicznych, Materiały pokonferencyjne VI Konferencji naukowej UZP, pod red. T. Kocowskiego, J. Sadowego, Wrocław-Warszawa 2013, s. 199-205; R. Tubisz, Środki ochrony prawnej i system organów je realizujacych na tle odwołania i funkcjonowania Krajowej Izby Odwoławczej, w: Prawo zamówień publicznych. Stan obecny i kierunki zmian, pod red. H. Nowickiego, P. Nowickiego, Wrocław 2015, s. 460; A. Panasiuk, Pozycja ustrojowa Krajowej Izby Odwoławczej, w: idem, System zamówień publicznych. Zarys wykładu, Warszawa 2013, s. 199-205.

2 Ł. Błaszczak, Moc wiążąca wyroków Krajowej Izby Odwoławczej w postepowaniach sadowych związanych ze zwrotem wadium, "Iustitia” 2013, nr 1, s. 7; K. Różowicz, Glosa do postanowienia Sądu Najwyższego z dnia 27 listopada 2014 r., sygn. IV CSK 115/14, "Studia Prawa Publicznego" 2016, nr 2, s. 169-182.

${ }^{3}$ Uchwała Sądu Najwyższego (SN) z 17 II 2016 r., sygn. III CZP 111/15, LEX nr 1977617. 
przez Krajową Izbę Odwoławczą (KIO), powziął wątpliwość, „czy dopuszczalna jest skarga od wyroku Krajowej Izby Odwoławczej w zakresie zarzutów oddalonych wyłącznie w uzasadnieniu wyroku Krajowej Izby Odwoławczej przy jednoczesnym braku takiego rozstrzygnięcia w sentencji wyroku Krajowej Izby Odwoławczej?".

Wskazana wątpliwość prawna powstała na tle nieskomplikowanego stanu faktycznego. KIO wydała wyrok uwzględniający odwołanie, jednakże w orzeczeniu nie uwzględniła wszystkich zarzutów i żądań odwołującego, a negatywne stanowisko dotyczące zasadności pominiętych w orzeczeniu zarzutów i żądań sformułowała w jego uzasadnieniu. W efekcie KIO oceniła zasadność wszystkich zarzutów i żądań, jednakże aprobatę dla części z nich zawarła w orzeczeniu, natomiast dezaprobatę dla pozostałych w uzasadnieniu do tego orzeczenia. $W$ tej sytuacji odwołujący złożył wniosek o uzupełnienie wyroku, który nie został uwzględniony przez KIO. Odwołujący, w którego ocenie orzeczenie KIO nie chroniło w sposób należyty jego interesu, wniósł skargę do sądu okręgowego.

Sąd Najwyższy, po rozpoznaniu przedstawionego mu zagadnienia prawnego, stanął na stanowisku dozwalającym na zaskarżanie zarzutów oddalonych w uzasadnieniu orzeczenia, a nierozstrzygniętych w sentencji.

Doniosłość przyjętej przez Sąd Najwyższy uchwały uwidacznia m.in. liczba dotychczas opublikowanych glos, które zostały jej poświęcone ${ }^{4}$. Pomimo ich wielości oraz ważkości czynionych w nich przemyśleń nie wszystkie kwestie problemowe zostały zauważone albo poruszone w zasługującym na to zakresie. Niniejsza glosa nie stanowi próby kompilacji dotychczas wyrażonych przez przedstawicieli doktryny stanowisk, niemniej jednak ze względu na doniosłą rolę, jaką spełnia dyskurs naukowy, nie zostały one pominięte.

\section{Istota wyroków wydawanych przez KIO}

Krajowa Izba Odwoławcza, będąca stałym i kolegialnym organem administracji publicznej, spełnia określone prawem funkcje jurysdykcyjne w zakresie wyspecjalizowanej dziedziny prawa, jaką stanowią

${ }^{4}$ M. Stawiński, Glosa do uchwaty Sądu Najwyższego z 17 lutego 2016 r., III CZP 111/15, „Palestra” 2016, nr 10, s. 131-137; R.R. Wasilewski, Glosa do uchwały Sadu Najwyższego z 17 lutego 2016 r., III CZP 111/15, „Finanse Komunalne” 2016, nr 10, s. 72-78; M. Sieradzka, Glosa do uchwaty Sądu Najwyższego z 17 lutego 2016 r., III CZP 111/15, LEX/el. 2016 nr 290651. 
zamówienia publiczne ${ }^{5}$. Realizacji wskazanej funkcji służy specjalna procedura postępowania odwoławczego, w ramach której KIO wydaje orzeczenia (postanowienia oraz wyroki - art. 192 ust. 1 ustawy Prawo zamówień publicznych ${ }^{6}$ ). Wyraźnie należy zastrzec, że wyroki wydawane przez KIO nie przynależą do tej samej kategorii indywidualnych aktów stosowania prawa co wyroki wydawane przez sądy powszechne czy sądy arbitrażowe. „Wyroki KIO stanowią sui generis prawną formę działania administracji w sprawach indywidualnych [...]. W pewnym zakresie zbliżone są do wyroków sądów polubownych, m.in. co do możliwości uzyskania przez nie mocy prawnej równej z wyrokiem sądu powszechnego. Wykazywanie pewnych cech wspólnych z wyrokami arbitrażowymi nie powinno jednak skutkować zaliczeniem ich do tejże kategorii, m.in. ze względu na niewątpliwie publicznoprawny status KIO. Jednocześnie należy podkreślić, że uzyskiwanie w pewnych sytuacjach przez te akty mocy prawnej równej z wyrokami sądów powszechnych nie stanowi przesłanki pozwalającej zaklasyfikować je do kategorii orzeczeń wydawanych przez organy sądownicze"7.

\section{Sentencja w wyrokach KIO}

Swoistość wyroków KIO uwidacznia się m.in. w tym, że zgodnie z regulacjami normatywnymi nie posiadają one wyraźnie wyróżnionej sentencji orzeczenia. Zarówno przepisy ustawy p.z.p., jak i Rozporządzenia Prezesa Rady Ministrów z dnia 22 marca 2010 r. ${ }^{8}$, odmiennie niż regulacje Kodeksu postępowania cywilnego ${ }^{9}$ czy ustawy Prawo o postępowaniu przed sądami administracyjnymi ${ }^{10}$, nie posługują się pojęciem "sentencji" w odniesieniu do wyroków. W § 32 Rozporządzenia ws. regulaminu użyto tego pojęcia,

${ }^{5}$ Zob. K. Różowicz, Charakterystyka środków ochrony prawnej przewidzianej przepisami ustawy Prawo zamówień publicznych, "Studia Prawa Publicznego" 2014, nr 4, s. 131-137.

${ }^{6}$ Ustawa z dnia 29 I 2004 r. Prawo zamówień publicznych (tekst jedn. Dz.U. 2015, poz. 2164 ze zm.), dalej „p.z.p.”.

${ }^{7}$ K. Różowicz, Charakter prawny wyroków wydawanych przez Krajową Izbę Odwoławcza, "Studia Prawa Publicznego" 2016, nr 2, s. 147-168.

${ }^{8}$ Rozporządzenie Prezesa Rady Ministrów z dnia 22 III 2010 r. w sprawie regulaminu postępowania przy rozpoznawaniu odwołań (tekst jedn. Dz.U. 2014, poz. 964), dalej "Rozporządzenie ws. regulaminu".

${ }^{9}$ Ustawa z dnia 17 XI 1964 r. Kodeks postępowania cywilnego (tekst jedn. Dz.U. 2014, poz. 101 ze zm.), dalej „k.p.c.”.

10 Ustawa z dnia 30 VIII 2002 r. Prawo o postępowaniu przed sądami administracyjnymi (tekst jedn. Dz.U. 2016, poz. 718), dalej "p.p.s.a.”. 
ale wyłącznie w odniesieniu do postanowień kończących postępowanie odwoławcze wydanych na posiedzeniu niejawnym. Pomimo nieposługiwania się przez ustawodawcę w regulacjach p.z.p. oraz Rozporządzenia ws. regulaminu pojęciem "sentencji wyroku" materia obligatoryjnych elementów orzeczenia została przez prawodawcę uregulowana w sposób zbliżony do przyjętego $\mathrm{w}$ ramach k.p.c. czy p.p.s.a. Zgodnie $\mathrm{z}$ art. 325 k.p.c. oraz 138 p.p.s.a. sentencja wyroku powinna zawierać:

1. wymienienie sądu (k.p.c.) albo oznaczenie sądu (p.p.s.a.);

2. wymienienie sędziów, protokolanta oraz prokuratora, jeżeli brał udział w sprawie (k.p.c.), albo imion i nazwisk sędziów, protokolanta oraz prokuratora, jeżeli brał udział w sprawie (p.p.s.a.);

3. datę i miejsce rozpoznania sprawy i wydania wyroku (k.p.c.i p.p.s.a.);

4. wymienienie stron (k.p.c.) albo imienia i nazwiska lub nazwy skarżącego (p.p.s.a.);

5. oznaczenie przedmiotu sprawy oraz rozstrzygnięcie sądu o żądaniach stron (k.p.c.) albo wskazanie przedmiotu zaskarżenia oraz rozstrzygnięcie sądu (p.p.s.a.).

Orzeczenie wydane przez KIO, zgodnie z $§ 34$ ust. 1 Rozporządzenia ws. regulaminu, zawiera:

1. rodzaj orzeczenia (wyrok, postanowienie);

2. miejsce i datę wydania;

3. wskazanie składu orzekającego, protokolanta, stron oraz uczestników postępowania odwoławczego;

4. w przypadku wyroku rozstrzygnięcie o żądaniach odwołującego albo odwołujących lub rozstrzygnięcie o karze finansowej, unieważnieniu umowy w całości bądź w części, o skróceniu okresu obowiązywania umowy albo o stwierdzeniu naruszenia przepisów ustawy;

5. rozstrzygnięcie o kosztach postępowania odwoławczego;

6. pouczenie o możliwości wniesienia skargi.

Wskazane w $\S 34$ ust. 1 pkt 1-4 Rozporządzenia ws. regulaminu elementy składowe orzeczenia wydawanego przez KIO są zbieżne ze składowymi sentencji orzeczeń sądów cywilnych oraz administracyjnych. Powyższe ukazuje, że nieścisłość, jakiej dopuścił się SN w uchwale, ma wyłącznie charakter terminologiczny i nie wpływa na aspekty merytoryczne. Dodatkowo należy zauważyć, że również KIO w uzasadnieniach swoich wyroków posługuje się pojęciem "sentencji"11. Zatem nieścisłość tę można uznać za powszechnie występująca, a spór w tym zakresie należałoby uznać za logomachię.

\footnotetext{
${ }^{11}$ Zob. wyrok KIO z 19 IV 2016 r., sygn. KIO 500/16, LEX nr 2026099.
} 


\section{Odrębność uzasadnienia}

Prawodawca dookreślił nie tylko elementy składowe wyroków wydawanych przez KIO, ale również ich uzasadnienia. Zgodnie z art. 196 ust. 4 p.z.p. "uzasadnienie wyroku zawiera wskazanie podstawy faktycznej rozstrzygnięcia, w tym ustalenie faktów, które Izba uznała za udowodnione, dowodów, na których się oparła, i przyczyn, dla których innym dowodom odmówiła wiarygodności i mocy dowodowej, oraz wskazanie podstawy prawnej wyroku z przytoczeniem przepisów prawa". Przywołana regulacja, poprzez wskazanie elementów uzasadnienia, określa również funkcję, jaką ma ono pełnić. Jego istota sprowadza się do wyjaśnienia powodów przyjęcia określonego stanowiska wyrażonego w orzeczeniu. Znaczenie uzasadnienia przejawia się $w$ tym, że ma ono dać rękojmię, iż KIO dołożyła należytej staranności przy podejmowaniu rozstrzygnięcia, ma ono umożliwić sądowi okręgowemu ocenę przesłanek, na których oparła się KIO, ma przekonać strony do wydanego rozstrzygnięcia ${ }^{12}$. $Z$ uzasadnienia wynika również oczekiwany przez KIO sposób wykonania wydanego orzeczenia co do istoty sprawy. Uzasadnienie pełni zatem rolę akcesoryjną względem orzeczenia i ma umożliwić zapoznanie się z przyczynami przyjęcia określonego rozstrzygnięcia.

Przywołany art. 196 ust. 4 p.z.p., a także inne regulacje zawarte w p.z.p., w tym m.in. art. 196 ust. 3 p.z.p., wyraźnie wskazują, że odmiennie niż w przypadku decyzji administracyjnych, dla których uzasadnienie faktyczne i prawne jest ich obligatoryjną składową (art. 107 Kodeksu postępowania administracyjnego ${ }^{13}$ ), uzasadnienie wyroku KIO jest odrębnym od orzeczenia elementem. Nie zmienia tego istnienie pomiędzy uzasadnieniem a orzeczeniem ścisłego związku. Pogląd o odrębności tych dwóch elementów znajduje również potwierdzenie w powszechnie akceptowanym zapatrywaniu, iż brak uzasadnienia orzeczenia KIO nie ma wpływu na jego istnienie, pomimo że uzasadnienie organ ten sporządza $z$ urzędu ${ }^{14}$. W ramach p.z.p. ustanowiono rozwiązanie zbieżne z przyjętymi w k.p.c. (art. 328 § 1) czy p.p.s.a. (art. $141 \S 1$ ).

12 Zob. J. Zimmermann, Motywy decyzji administracyjnej i jej uzasadnienie, Warszawa 1981, s. 161-164.

${ }^{13}$ Ustawa z dnia 14 VI 1960 r. Kodeks postępowania administracyjnego (tekst jedn. Dz.U. 2016, poz. 23).

${ }^{14}$ Zob. uzasadnienie uchwały SN z 9 II 2009 r., sygn. III CZP 38/39, OSNC 2000, nr 7-8, poz. 126 . 
$\mathrm{W}$ rezultacie nieuprawnione jest utożsamianie orzeczenia $\mathrm{z}$ jego uzasadnieniem, a także przenoszenie obligatoryjnych elementów orzeczenia do jego uzasadnienia (i vice versa). Nie powinno zatem budzić wątpliwości, że rozstrzygnięcie powinno zostać zawarte w orzeczeniu, a nie w jego uzasadnieniu. Takie stanowisko przyjął również SN w głosowanej uchwale i zasługuje ono na pełną aprobatę.

\section{4. Żądanie a zarzuty odwołania}

Należy jednak zauważyć, że SN w swojej uchwale przyjął, iż „dopuszczalna jest skarga [...] dotycząca zarzutów oddalonych w uzasadnieniu [...] orzeczenia, a nierozstrzygniętych w sentencji". Klarowność treści uchwały przesądza o tym, że podejmując ją, SN przyjął, iż de lege lata KIO w orzeczeniu wieńczącym postępowanie odwoławcze powinna rozstrzygnąć o zarzutach wskazanych w odwołaniu. Tak określony obowiązek nie został przewidziany w przepisach prawnych, także w tych, które zostały przywołane przez SN w uzasadnieniu uchwały (art. 192 ust. 7 p.z.p. i § 34 ust. 1 pkt 4 Rozporządzenia ws. regulaminu).

Zgodnie z art. 192 ust. 7 p.z.p. „Izba nie może orzekać co do zarzutów, które nie były zawarte w odwołaniu". Tożsama merytorycznie reguła została odniesiona do postępowania skargowego. Artykuł 198 f ust. 4 p.z.p. wyklucza możliwość orzekania przez sąd co do zarzutów, które nie były przedmiotem odwołania. Z kolei $\S 34$ ust. 1 pkt 4 Rozporządzenia ws. regulaminu zobowiązuje KIO do zawarcia w wyroku "rozstrzygnięcia o żądaniach odwołującego albo odwołujących".

Już pobieżna analiza tych dwóch regulacji pozwala dostrzec, że posługują się one dwoma odrębnymi pojęciami: "zarzut” oraz „żądanie”. Ich odmienność znaczeniową najlepiej ukazuje art. 180 ust. 3 p.z.p., zgodnie z którym odwołanie powinno zawierać m.in. zarzuty oraz określać żądanie odwołującego. Pomimo nieistnienia legalnej definicji tych dwóch pojęć na podstawie analizy całokształtu przepisów p.z.p. można przyjąć, że zarzutem jest wskazanie „czynności lub zaniechanie czynności zamawiającego, której zarzuca się niezgodność z przepisami ustawy" (art. 180 ust. 1 i 3 p.z.p.). Zgodnie z dyspozycją art. 180 ust. 3 p.z.p. zarzut powinien zostać zwięźle przedstawiony w treści odwołania. $Z$ kolei żądaniem odwołujący wskazuje, jakiego zachowania domaga się od zamawiającego, a tym samym jakie zachowanie powinno zostać mu nakazane przez KIO. Prawidłowo skonstruowana treść żądania 
powinna zostać skorelowana z treścią nakazu, jaki w swoim orzeczeniu może zawrzeć KIO. Został on ustawowo doprecyzowany w ramach art. 192 ust. 3 p.z.p. W sytuacji, w której umowa w sprawie zamówienia publicznego nie została zawarta, KIO może: nakazać wykonanie lub powtórzenie czynności zamawiającego lub nakazać unieważnienie czynności zamawiającego (art. 192 ust. 3 pkt 1 p.z.p.).

Rekapitulując powyższe, zarzutami odwołujący wskazuje, jakich naruszeń procedury o udzielenie zamówienia publicznego dopuścił się zamawiający (w ocenie odwołującego), a żądaniami określa oczekiwania względem przyszłego zachowania gospodarza postępowania, które mają konwalidować zaistniałe nieprawidłowości.

Poczynione rozróżnienie, przynajmniej z dwóch powodów, ma doniosłe znaczenie praktyczne. Po pierwsze, „Izba, uwzględniając zarzuty odwołania, których zakresem jest związana [...] jednocześnie nie będąc związana żądaniami odwołania, może orzec inaczej, aniżeli wnosił odwołujący"15. W rezultacie braku związania KIO żądaniami, treści nakazanego zamawiającemu zachowania nie determinuje wola odwołującego. Po drugie, prawodawca nie zobligował KIO do zawierania w orzeczeniu rozstrzygnięć dotyczących zarzutów odwołania. Dyspozycja § 34 ust. 1 pkt 4 Rozporządzenia ws. regulaminu w sposób niebudzący wątpliwości interpretacyjnych przewiduje obowiązek rozstrzygnięcia w wyroku żądań przedstawionych przez odwołującego albo odwołujących. Zważając na odrębność wskazanych pojęć, nie wydaje się zasadne rozszerzenie dyspozycji wskazanego przepisu i wywodzenie z niego obowiązku zawarcia w wyroku rozstrzygnięcia o zarzutach odwoławczych. Za niebudzące wątpliwości należy uznać, że odniesienie się do zarzutów (ich rozstrzygnięcie) następuje w uzasadnieniu orzeczenia, a jak już zostało w niniejszej glosie wskazane, elementów składowych tych dwóch dokumentów nie wolno przenosić.

W świetle powyższego powstają poważne wątpliwości dotyczące zasadności przyjętej przez SN uchwały, albowiem tenże organ sądowniczy, podejmując ją, przyjął odmienny niż istniejący de lege lata zakres obowiązkowych elementów orzeczenia. Wadliwości tej nie można postrzegać w kategoriach błędu terminologicznego. Ma on istotne znaczenie merytoryczne, albowiem nieuzasadnione jest uznawanie wyroków pozbawionych rozstrzygnięcia zarzutu albo zarzutów za wadliwe. Niezależnie od przyjętej metody sanowania nieprawidłowości

${ }^{15}$ Wyrok KIO z 19 IV 2016 r., sygn. KIO 500/16, LEX nr 2026099. 
występujących w orzeczeniach wydawanych przez KIO nie można jej stosować do błędów nieistniejących, a zatem do wyroków kompletnych. Pomimo że niewątpliwie należy zgodzić się z tezą SN o konieczności zawarcia przez KIO w wyroku wszystkich elementów obligatoryjnych i niemożliwości przenoszenia ich do uzasadnienia, jednak nie sposób przyjać, że organ ten ma obowiązek zawrzeć w wyroku elementy niewskazane wyraźnie w p.z.p. oraz Rozporządzeniu ws. regulaminu jako składowe orzeczenia. Krajowa Izba Odwoławcza, jak każdy organ władzy publicznej, związana jest konstytucyjną zasadą legalności i wydawane przez nią indywidualne akty stosowania prawa powinny być zgodne z wzorcem normatywnym. Nie powinny go zatem również modyfikować w nieuprawniony sposób.

\section{Konsekwencje procesowe niekompletności orzeczenia}

Niezależnie od dotychczas przedstawionych wątpliwości dotyczących głosowanej uchwały SN należy zastanowić się nad konsekwencjami proceduralnymi niekompletności orzeczenia KIO. Pominięcie przez KIO w wydanym orzeczeniu rozstrzygnięcia o żądaniach odwołującego stanowi jego wadę. Niezwiązanie tego organu żądaniami odwołującego nie może być bowiem odczytywane jako uprawnienie do traktowania ich jako nieistniejących. Obowiązek wyrażony w $§ 34$ ust. 1 pkt 4 Rozporządzenia ws. regulaminu należy rozumieć jako nakaz rozważenia zasadności żądań odwołującego i ukazania efektu podjętego procesu myślowego w orzeczeniu. Tak więc niezależnie od tego, czy KIO uwzględnia odwołanie, czy je oddala, nie może w wyroku pomijać żądań przedstawionych przez odwołującego, w tym także tych, które nie pozostają w zgodności z rodzajem wyroku wydawanego przez KIO. Jednocześnie w rozstrzygnięciu KIO powinna wyraźnie przesądzić, jakie czynności zamawiający zobowiązany jest podjąć (nakazać wykonanie lub powtórzenie czynności zamawiającego lub nakazać unieważnienie czynności zamawiającego). Wskazania powinny być jednoznaczne, niewątpliwe, konkretne, tak by zamawiający miał możliwość usunięcia uchybień.

Niekompletność orzeczenia wydanego przez KIO należy rozpatrywać w kontekście teorii orzeczenia nieistniejącego (sententia non existens). Na powyższe w swojej glosie uwagę zwrócił R.R. Wasilewski. „Ujmując w skrócie problem orzeczeń nieistniejących, należy 
zaznaczyć, że choć nie ma powszechnej zgody co do przesłanek uznania danego orzeczenia za nieistniejące, to często $\mathrm{w}$ literaturze oraz judykaturze prezentowany jest pogląd, według którego orzeczeniem nieistniejącym jest takie, które nie jest $\mathrm{w}$ ogóle sformułowane albo nie zawiera istotnych elementów (w tym np. podpisów całego składu orzekającego), czy wreszcie nie zostało ogłoszone (jeżeli prawo tego wymaga). Odwołując się do okoliczności sprawy leżącej u podstaw podjęcia przez SN glosowanej uchwały, należy stwierdzić, że zamieszczone przez KIO rozstrzygnięcie odwołania w uzasadnieniu, a nie sentencji wyroku, powinno być traktowane właśnie jako wyrok nieistniejący"16.

Zaistnienie takiej wady orzeczenia pociąga za sobą istotne konsekwencje i z tego względu powinno być możliwe do wyeliminowania. Sąd Najwyższy przyjął, że jest to możliwe poprzez dozwolenie wniesienia skargi nie tylko od orzeczenia, ale również od jego uzasadnienia. Należy jednak zauważyć, że stanowisko takie nie pozostaje w zgodności z treścią regulacji prawnych. Ustawodawca expressis verbis wskazał, że skarga przysługuje na orzeczenia KIO, a nie na jego uzasadnienia (art. 198a ust. 1 p.z.p.). Treść uzasadnienia uchwały wskazuje na to, że SN zauważył ten problem, jednocześnie odwołując się do nieakceptowalnych konsekwencji, jakie wynikają z przyjęcia wyniku literalnej interpretacji regulacji p.z.p. W uzasadnieniu SN podniósł, że „niewątpliwie zaskarżony wyrok KIO pozostaje niezgodny z żądaniem zgłoszonym przez K.W. S.A. w odwołaniu. Skarżąca pozostaje zatem pokrzywdzona tym orzeczeniem, jako że - jak wyjaśnił Sąd Najwyższy w uchwale składu siedmiu sędziów (zasada prawna) z dnia 15 maja 2014 r., III CZP 88/13, OSNC 2014, nr 11, poz. 108 - rezultat taki powstaje wówczas, gdy zaskarżone orzeczenie jest obiektywnie w sensie prawnym niekorzystne dla skarżącego, gdyż z punktu widzenia jego skutków związanych z prawomocnością materialną skarżący nie uzyskał takiej ochrony prawnej, którą zamierzał osiągnąć przez procesowo odpowiednie zachowanie $\mathrm{w}$ postępowaniu poprzedzającym wydanie orzeczenia". Nadto w części końcowej uzasadnienia uchwały SN wskazał, że „wadliwa praktyka orzekania w uzasadnieniu wyroku, a nie w jego sentencji o części zarzutów i żądań zawartych w odwołaniu nie może zamykać - przewidzianego w art. 78 Konstytucji - prawa do zaskarżenia wyroku wydanego w pierwszej instancji".

\footnotetext{
${ }^{16}$ R.R. Wasilewski, op. cit., s. 75.
} 
Przyjęcie przez SN stanowiska wyrażonego w uchwale należy uznać za przejaw kierowania się wartościami (duchem) prawa, a nie jego literą. Ocena zasadności stanowiska wyrażonego przez SN wymaga refleksji nad tym, czy w świetle obowiązujących regulacji prawnych przyjęte rozwiązanie jest jedynym pozwalającym na ochronę przed niekompletnością orzeczenia wydanego przez KIO, a w efekcie, czy zasadne jest dozwolenie na zaskarżenie uzasadnienia orzeczenia w przypadku niezawarcia w wyroku rozstrzygnięcia o wszystkich żądaniach, co pozostaje w sprzeczności zarówno z literą prawa, jak i wypracowanym dorobkiem doktryny.

\subsection{Skarga na niekompletne orzeczenie}

W pierwszej kolejności należy się zastanowić, czy istnieje możliwość zaskarżenia niekompletności orzeczenia KIO (postawienia zarzutu wadliwości wyroku ze względu na jego niekompletność), z wykorzystaniem przewidzianych w p.z.p. środków ochrony prawnej.

Kwestię tę należy rozstrzygnąć $\mathrm{z}$ uwzględnieniem roli, jaką w procedurze hybrydowej pełni postępowanie skargowe. Ma ono służyć zagwarantowaniu możliwości weryfikacji orzeczeń wydanych przez organ administracji publicznej przez judykatywę ${ }^{17}$, a także realizacji zasady dwuinstancyjności postępowania ${ }^{18}$. Pomijając budzącą w doktrynie wątpliwości kwestię dopuszczalności zaskarżania postanowień niekończących postępowania w sprawie ${ }^{19}$, należy zauważyć, że w sytuacji, w której sąd okręgowy po raz pierwszy orzekałby o żądaniach pominiętych w orzeczeniu przez KIO, w istocie nie pełniłby swojej roli, ale zastępował ten organ. W efekcie strony postępowania nie miałyby zagwarantowanego,

${ }^{17}$ Wymóg taki wynika bezpośrednio z Dyrektywy Rady 89/665/EWG z dnia 21 XII 1989 r. w sprawie koordynacji przepisów ustawowych, wykonawczych i administracyjnych odnoszących się do stosowania procedur odwoławczych w zakresie udzielania zamówień publicznych na dostawy i roboty budowlane (Dz.Urz. WE L 395 z 30 XII 1989 r., s. 33) oraz Dyrektywy Rady 92/13/EWG z dnia 25 II 1992 r. koordynującej przepisy ustawowe, wykonawcze i administracyjne odnoszące się do stosowania przepisów wspólnotowych w procedurach zamówień publicznych podmiotów działających w sektorach gospodarki wodnej, energetyki, transportu i telekomunikacji (Dz.Urz. WE L 76 z 23 III 1992 r., s. 14).

${ }^{18}$ Jedynie na marginesie należy zauważyć, że realizacja przez ukształtowany w ramach p.z.p. system środków ochrony prawnej wskazanej zasady może budzić wątpliwości, zob. K. Różowicz, Charakterystyka środków ochrony prawnej..., s. 147-148.

${ }^{19}$ Zob. R.R. Wasilewski, op. cit., s. 77. 
przewidzianego w art. 78 Konstytucji Rzeczypospolitej Polskiej ${ }^{20}$, prawa do zaskarżenia wyroku wydanego w pierwszej instancji.

Na marginesie, należy poddać pod rozwagę, czy zasadniczo identyczna sytuacja nie ma miejsca, jeżeli KIO rozstrzyga o niektórych żądaniach odwołania w uzasadnieniu orzeczenia. Skoro uzasadnienie orzeczenia nie jest elementem tego aktu stosowania prawa, to $\mathrm{w}$ rezultacie pierwszym orzeczeniem, w którym nastąpi rozstrzygnięcie o żądaniach strony, będzie wyrok sądu okręgowego, zamykający drogę sądową. Zdaje się jednak, że przyjęcie możliwości zaskarżenia uzasadnienia orzeczenia (jak uczynił to w głosowanej uchwale SN) w szerszym zakresie realizuje wymogi konstytucyjne niż przyjęcie możliwości zaskarżenia niekompletnego wyroku KIO i traktowanie rozstrzygnięcia zawartego w uzasadnieniu jako nieistniejącego.

\subsection{Ponowienie odwołania}

Sąd Najwyższy w uzasadnieniu uchwały zauważa, że „zgodnie z utrwalonym stanowiskiem judykatury, pominięcie przez sąd w sentencji wyroku rozstrzygnięcia o całości żądania nie daje podstawy do jego zaskarżenia z tej przyczyny; strona może [...] wystąpić z powództwem obejmującym żądanie nierozstrzygnięte. Rozstrzygnięcie przedstawionego zagadnienia prawnego w oparciu o przytoczoną regułę nie mogłoby jednak być uznane za uzasadnione, skoro [...] przepisy ustawy Prawo zamówień publicznych wyłączają dopuszczalność wniesienia kolejnego odwołania opartego na tych samych okolicznościach, które były przedmiotem rozstrzygnięcia w sprawie innego odwołania dotyczącego tego samego postępowania, wniesionego przez tego samego odwołującego się (art. 189 ust. 2 pkt 4 u.p.z.p.)".

Należy w pełni podzielić pogląd wyrażony przez $\mathrm{SN}$, jedynie uzupełniająco wskazując, że zmodyfikowanie przywołanego art. 189 ust. 2 pkt 4 p.z.p., np. na wzór art. $199 \S 1$ pkt 2 k.p.c., de facto jedynie wyjątkowo umożliwiałoby ponowne wniesienie odwołania w zakresie żądań nierozstrzygniętych, ze względu na niezwykle krótkie terminy na dokonanie tej czynności określone w art. 182 p.z.p. Złożenie odwołania po upływie ustawowo określonego terminu zawsze skutkuje jego odrzuceniem (art. 189 ust. 2 pkt 3 p.z.p.).

${ }^{20}$ Konstytucja Rzeczypospolitej Polskiej z dnia 2 IV 1997 r. (Dz.U. Nr 78, poz. 483 ze zm.), dalej „Konstytucja RP”. 


\subsection{Wniosek o uzupełnienie orzeczenia}

W głosowanej uchwale Sąd Najwyższy jako jedną z rozpatrywanych możliwości wskazał również złożenie wniosku o uzupełnienie orzeczenia, jeżeli jest ono niekompletne. Zgodnie z art. 1202 k.p.c. (do którego należy się odwołać na podstawie art. 185 ust. 7 p.z.p.) strona postępowania może „zwrócić się do sądu polubownego w terminie miesiąca od dnia otrzymania wyroku $\mathrm{z}$ wnioskiem o jego uzupełnienie co do żądań zgłoszonych w postępowaniu, o których sąd polubowny nie orzekł w wyroku. Po rozpoznaniu wniosku sąd polubowny wydaje wyrok uzupełniający w terminie do dwóch miesięcy od dnia złożenia wniosku". Regulację tę należy stosować odpowiednio do wyroków wydawanych przez KIO, a zatem jeżeli są one niekompletne, strona odwołująca powinna złożyć wniosek o uzupełnienie. W przypadku wydania postanowienia oddalającego wniosek strony na takie orzeczenie odwołujący powinien skierować skargę do sądu okręgowego.

„Przyjęcie, że na postanowienie KIO oddalające wniosek o uzupełnienie wyroku przysługuje skarga, powoduje jednak problem, w jaki sposób wniesiona w takim zakresie skarga powinna zostać rozstrzygnięta, bowiem sąd - rozpoznając skargę na orzeczenie KIO - zgodnie $\mathrm{z}$ art. $198 \mathrm{f}$ ust. 2 p.z.p. może skargę oddalić, jeżeli jest bezzasadna, albo zmienić orzeczenie KIO i orzec co do istoty sprawy. Nie występuje jednak w ramach postępowania skargowego możliwość uchylenia orzeczenia KIO, ponieważ przepis ten wyłącza zastosowanie art. 386 $\S 4$ k.p.c., pozwalający w postępowaniu apelacyjnym na uchylenie wyroku. Gdyby przyjąć, że w takim przypadku sąd powinien zmienić postanowienie KIO $\mathrm{w}$ ten sposób, że dokonałby uzupełnienia wyroku $\mathrm{KIO}$, to powstałby kolejny problem, tym razem związany z możliwością i trybem zaskarżenia takiego orzeczenia. Mianowicie należałoby się zastanowić, czy od takiego orzeczenia przysługiwałaby skarga, bowiem $\mathrm{w}$ tym zakresie byłoby to co do odwołania rozstrzygnięcie I instancji" $^{\prime 21}$. W świetle obowiązujących regulacji normatywnych nie istnieje możliwość zaskarżenia wydanego przez sąd okręgowy wyroku, zatem również ta droga ochrony interesu strony nie pozostaje w zgodności $\mathrm{z}$ art. 78 Konstytucji RP.

\footnotetext{
${ }^{21}$ R.R. Wasilewski, op. cit., s. 77-78.
} 


\section{Podsumowanie}

Podjęta przez SN uchwała nie zasługuje na aprobatę $w$ zakresie, $w$ jakim nakłada na KIO obowiązek rozstrzygania w wyroku o zarzutach odwoławczych. Regulacje p.z.p. oraz Rozporządzenia ws. regulaminu nie zawierają takiego obowiązku, a w świetle zasady legalizmu KIO powinna wydawać orzeczenia zgodne z wzorcem normatywnym. Również dopuszczenie możliwości zaskarżenia uzasadnienia orzeczenia budzi wątpliwości teoretyczne oraz praktyczne. W świetle obowiązujących regulacji normatywnych niekompletność orzeczenia KIO powinna skutkować odrzuceniem skargi przez sąd okręgowy. Zważając jednak na argumenty przemawiające za odstąpieniem od literalnej interpretacji przepisów p.z.p. oraz Rozporządzenia ws. regulaminu, stanowisko SN należy ocenić jako słuszne i w tym zakresie godne aprobaty. Zauważenia wymaga, że rozwiązanie przyjęte $w$ uchwale ma ograniczony zasięg zastosowania praktycznego, albowiem nie rozwiązuje zasadniczo identycznego problemu pojawiającego się w sytuacji, w której KIO nie rozstrzygnie o żądaniach ani w orzeczeniu, ani w jego uzasadnieniu. Powyższe wskazuje na nieodzowność podjęcia ingerencji przez ustawodawcę $\mathrm{w}$ celu przyjęcia regulacji umożliwiających skuteczne weryfikowanie efektów działalności KIO i eliminowanie występujących w nich nieprawidłowości. W analizowanym przypadku celowe wydaje się przyznanie sądom powszechnym kompetencji do uchylenia zaskarżonego wyroku KIO i przekazania sprawy do ponownego rozpoznania. Zważając jednak na mnogość występujących w tym obszarze problemów, zasadny zdaje się postulat reformy systemowej pozwalającej na poprawę realnej ochrony interesu prywatnego oraz publicznego w sferze administracyjnego oddziaływania na procesy udzielania zamówień publicznych. 